\title{
Youth's Interests in Professions a Soci-Field Study for the City of Baghdad
}

\author{
Assist. Prof. Dr. Hani Ahmed Yonis \\ Al-Iraqia University, College of Media, Iraq \\ Received: 01 Oct 2021; Received in revised form: 28 Oct 2021; Accepted: 04 Nov 2021 \\ (C2021 The Author(s). Published by TheShillonga. This is an open access article under the CC BY license \\ (https://creativecommons.org/licenses/by/4.0/)
}

\begin{abstract}
Paying attention to the affairs of young people, their circumstances, their attitudes, and undoubtedly about work and the practice of a certain profession, helps to identify their reality, aspirations, problems, and the reasons that motivate them to go to a particular job, stay away from the other, and fulfill their various needs. The importance of the study lies in the noticeable increase in interest in youth, and the issue of youth and their work has become one of the important topics, due to the effective and influential role they play in the progress and development of societies and nations. A special issue that the researcher needs in his theoretical and practical study to collect scientific facts. The study included an intentional sample of young people and others who are able to work in different professions, whose ages range between (18-46) years only. The city of Baghdad was chosen because it is one of the millions of cities in the world and from the various governorates of the country. The study aimed to:
\end{abstract}

1- Identifying the trends and motives of young people towards professions.

2- Knowing the reasons that make a particular profession higher than others.

3-Identifying the hierarchical order of the position of professions in Baghdadi society.

This has shown the most important results of the study objectives:

- $\quad$ The first objective

Financial / high wages for his work.

Psychological / the individual's desire to achieve social relations and respect for others.

Social / Achieving a prestigious social position in society.

- $\quad$ The second objective

The study concluded that there are reasons for young people's motives towards choosing a profession related to the nature of their personal qualifications on the one hand, and what they get (financially and morally) from this profession, as follows:

- High wages

- Availability of opportunities for advancement and development

- Profession stability and stability in general

- Less risks and problems

- Social relations

- Lack of effort

The third objective occupied the first five ranks of the hierarchy of jobs for their priority and importance, which are as follows (university professor, doctor, engineer, teacher, lawyer, officer, public servant, ...etc. This shows the respondents' interest in governmental jobs for economic and social motives. The most important recommendation has been shown in the 
study: creating a balance between workers in the field of professional work and workers in the field of professional selfemployment in order to advance sound development plans, through development programs presented by the media. employees in other professional sectors.

Keywords-Society, professions, youth, job opportunities, and private and governmental jobs.

\section{INTRODUCTION}

Work remains an important source in which man fulfills his various needs in addition to the requirements of his continuity of living. Therefore, the issue of the social status of the profession is one of the important topics in the social, societal and economic literature, because it is directly related to human life in various societal societies, and the goal behind which man seeks to prove his selfexistence to others through the mirror of the profession and job opportunities, As it is known that there are a number of different factors such as political, economic, and social that affect the profession's growth and decline. Paying attention to the affairs of young people, their circumstances and their attitudes, and undoubtedly towards work, helps in identifying their reality, aspirations, problems, and the reasons that motivate them to go towards a specific job and stay away from the other, and the obstacles that stand in their way, as when they are identified, they can be resolved, as well as directing them in the right direction and providing them with appropriate job opportunities that achieve their goals and the goals of their society.

\section{THE STUDY PROBLEM}

The social position or social rank in sociology or anthropology is the respect or reputation related to the position of the individual in any society, and it may also return to the rank or position of the person that is characterized by him within the group.

The profession is a basic test for the role of man and hence his position within his society, and every job has a hierarchy of social status. As the position occupied by the individual, the family or the group, it determines the duties, roles, rights, behavior and social relations that bind the community with each other, and thus their distribution varies in the hierarchy of social status. Among the factors affecting these centers is the profession practiced by the individual within the various institutions of society.

\section{THE IMPORTANCE OF THE STUDY}

The interest in youth has increased significantly, and the issue of youth has become one of the important issues, due to the effective and influential role they play in the progress of peoples and nations and the development of societies. Also, caring for them means caring for the society as a whole, its present and its future, as they represent a base for the future and the basic workforce. This study is one of the social studies that paid clear attention to determining the social status of work by knowing the community's motives for practicing it, and for the lack of societal and social studies that study the youth in Iraqi society in general and the city of Baghdad in particular. Various work and professions.

\section{THE OBJECTIVES OF THE STUDY}

The study aimed to show the following:

1- Identifying the trends and motives of young people towards practicing a profession and not others.

2- Knowing the reasons that make a particular profession higher than others, according to social status and social structure.

3- Identifying the hierarchical order of the status of professions according to the point of view of the Baghdadi society.

\section{STUDY METHODOLOGY}

This study has relied on the descriptive analytical method and the field social survey in shedding light on the reality of the Iraqi society in general and the Baghdadi society in particular, which the researcher needs in his theoretical and practical study to collect scientific facts.

\section{FIELDS OF STUDY}

The main aim of the study is to focus on the following fields:

The human field: it included an intentional sample of young people and others who are able to work in different professions, whose ages range between (18-46) years only.

Spatial Domain: The city of Baghdad is considered as a spatial field of study.

Time Domain: the study continued from $1^{\text {st }}$ of January, 2020 until May, 2021. 
VII.

\section{THEORETICAL FRAMEWORK FOR THE STUDY}

\subsection{The first topic: concepts and terminology of the study}

Determining scientific concepts and terms is necessary in academic research. The more accurate and clear this identification is, the easier it will be for readers who follow the research to understand the meanings and ideas that the scholar wants to express without differing in understanding what he says. The concepts of the study are the most important factor for understanding the meaning of the term and the concept and clearing the ambiguity, lack of understanding, ambiguity and interference in the reader's thoughts, and among the most important concepts and terms are trends, working manpower, profession, and social prestige (Hassan, 1971).

\section{- Directions}

Despite the great importance of trends in determining individuals' responses and directing their behavior, there is no clear agreement on a specific definition, as its definitions are numerous and vary as much as it is studied and analyzed.

The term "positions" is an Arabic translation of the term "Attitudes" in the English language, and the philosopher Spencer (1984) was the first to use it in 1862 in his book First Principles when he said "Our access to correct rulings on issues that raise a lot of controversy, depends to a large extent on our mental attitude as we listen to this debate and participate in it".

Allport (1971) defined attitude as "a state of mental and nervous readiness, which is organized through experience, and exerts a directive or dynamic influence on a person's response to all the topics and situations to which they are associated".

Bogardus (1988) defines it as "a tendency that tends to behave close to or away from some environmental factors, and gives them positive or negative criteria according to their attraction to or aversion to them".

Attitudes can be defined as the individual's willingness to respond, he acquires from his interaction with his social environment towards topics, issues, actions and groups, either by acceptance or rejection, and works to define and direct his social behavior.

\section{- Working manpower}

The working human force has been defined as "that part of society that can be exploited in economic activity, and it is the whole of society, excluding those who are unable to work and they are children and the elderly" (Sufuh,1980).
The workforce can be defined procedurally professional 18 years and the maximum work limit 46 years and those who are able to profession, produce goods and provide services.

\section{- Profession}

The profession was defined as "a craft or service that depends on a set of information that a person uses at the time of performing the service needed by society" (Michelle, 1980).

It is also defined as "the set of interconnected and distinct actions that a person performs in a specific place and time" (Mohammed,1986).

It is known as "the administrative, muscular and mental profession that a person makes in return for a specific wage or salary" (Ihssan,1990),

As for the job "it means the profession that the employee is required to perform" (Tahseen,1991).

The meanings in which the function was used in sociology can be defined in five distinct meanings to some extent the first is what a person engages in social activity and the second refers to the profession or job in that it prepares the person who undertakes it for profit and gain. The third means the activist ranked in a social position, and the fourth is related to mathematical usage, in which it refers to the relationship between variables, and the fifth and last linked to the concept of function in biological sciences (Al-Saed,1993).

The procedural definition of the profession, so it can be defined as the basic and usual work that a person does to meet the requirements of his livelihood, and he needs experience, skill, and practice.

- Social status

The status or rank of a person or group in society is known as the social status and may be determined in two ways. People can obtain their social status through their personal achievements, which is known as the acquired status. Alternatively, one can take a place in the social system by means of his inherited position, which is called an ascribed position. Attributable positions may also be defined as those held for an individual from birth. Or the ascribed positions that exist in all societies classified according to gender, age, ethnic tribes, and the origins of families, they are given and learned many laws and social roles as if they were socially increased in a family that has become equipped with all these features and advantages. Acquired positions also mean what a person has acquired during his life as a result of the acquisition of knowledge, ability, skill or perseverance and the profession provides an example of a position that can be either affiliated or acquired, which can be acquired by the victory of someone with the right awareness and skills to become a social 
position in a high position in the job; Or based on a person's social identity within the job.

The social position is the position associated with the distribution and identification of considerations within a particular social system, and sometimes with regard to determining rights, obligations, influence and power within the system, as it is known that there is a high position, and a low position (Hisham, 2001).

It is also defined as a social rank and position occupied by man in his societal society (Ma'an, 1990). Prestige is acquired by different means depending on the conditions of society and the extent of its civilization and culture. It may be acquired through family, lineage, money and prestige. takeover or work (Ibrahim, 1975).

It can also be defined as what an individual achieves in terms of appreciation, respect and influence on others through the skills and behavior that he emits towards them and which he acquires through belonging to a family or group, or through education, authority, profession or prestige.

\subsection{The second topic, professional work and its social advantages.}

Professions differ among themselves, and the history of any profession reflects the society and society's view of it, as society recognized its importance, and the degree of society's respect for the individuals working in it, or through the privileges offered by the profession to its owners (Ahmed, 1990). Society is production, art and culture, as it is the essential form of human activity and the open arena for human liberation and development of capabilities (Abdulbasit, 1995).

Girth \& Mills (2002) considers the profession as one of the most important objective criteria that determine the social status of the population and the social class of the individual and refers to the social differences between society.

when we study professions, we must link them with their social positions, for professions are the ones that determine the degrees of respect, appreciation and social influence that their owners and those who occupy them obtain from other society, and some professions give those who practice them some power and influence over others, and this power may be directly in the case of the authority of a chief In order to understand the role of the profession in the class affiliation of the population, we must link the profession and social position on the one hand, and the profession and social power on the other hand. There is no doubt that this enables us to know the social class to which the community of practicing these professions belongs, As several measures show the social status of the profession.
In modern societies, the social influence of the individual is determined by the nature of the profession and the jobs he practices and which he presents to the community and the society around him. However, there are differences in social influence and power between one profession and another on the one hand, and between professions from one society to another, on the other hand and from The reason for this is due to cultures, customs, traditions, the social and economic value of the professions, and finally the conditions, qualifications and skills that must be available in the society who occupy them. The light of the source of income and its amount, and economic gradation is linked with gradation in social status, and income is a source of that gradation (William, 1964)

In contrast to the foregoing, there are professions that society is rushing to, not for the reason of their financial return alone, but because of the associated social gains related to the social status of the population, that is, there are social values that affect occupational preference related to the ease of the profession's conditions, and the possibility of benefiting from the job site to serve private projects. and joining the profession based on Krabian relationships and this is clearly observed in the Gulf model, where there is a strong tendency to the government profession and in the areas of administration precisely because of its distinguished position and influence. (Mohammed, 1985).

Therefore, it became clear to us that the social status of professions varies based on a number of facts and factors, foremost of which is the degree of necessity of society's need for the services of each of them, the frequency and type of that need, the professional nature and utilitarian nature that characterizes it, as well as the resulting financial incomes of particular importance in assessing that position, and perhaps this is one of the reasons for the great social appreciation that bestows on practitioners of functional professions such as medicine, university teaching, and engineering with different specializations, despite the increase of some non-scientific works in the previous years. (Hisham, 2001).

Since 1990 till 2003 the relative transformation of the social status of scientific professions, this social view has not changed for people with professions such as medicine, university teaching, and engineering that they are in the upper ranks of jobs and have a social status It is prominent in the Iraqi society in general and the Baghdadi society in particular, especially after the amendments and improvement in the salary scale in the last four years, and as a result of the unstable conditions that the society is going through, especially the lawlessness that limited the 
practice of many professions and the resort of many to studying in the government job aspect.

\section{VIII. THE PRACTICAL FIELD FRAMEWORK FOR THE STUDY}

\subsection{The first topic: the study sample and its preliminary results}

The study relied on the intended sample (meaning the immediate selection of ages) between (18-46) years of residents of the city of Baghdad in various professions (free and functional). The city of Baghdad was chosen because it is one of the million-population cities, in addition to being one of the cities in which social customs predominate that care about the professions practiced by man (governmental and free), and whose people have recently been noted to prefer government professions to stabilize their income and ensure their future.

The researcher relied on (the questionnaire) in his study, in addition to observations and personal interviews. The researcher reached to formulate a preliminary questionnaire whose paragraphs were collected from some literature, books and references), and presented this questionnaire to experts to take their opinions and suggestions, and then the questionnaire became ready in its final form. The data was measured using the means The statistical (percentages, and hierarchical sequence), and the questionnaire form consisted of the general (initial) data and the specialized questions of the study:

1. The general (initial) data of the sample:

- The gender sample

The concept of gender equality is a concept as old as humanity, advocated by all heavenly and earthly laws. For example, the Islamic religion emphasized gender equality in basic aspects for man in his life, despite the difference in the human element, but equality in duties was and still is a demand of humanity, especially women, and from Important variables in descriptive studies because they reflect the variance between the human element.

Table No.1 Shows the gender difference in the study sample

\begin{tabular}{|c|c|}
\hline Gender & Percentage \\
\hline Male & $60 \%$ \\
\hline Female & $40 \%$ \\
\hline Total & $100 \%$ \\
\hline
\end{tabular}

Table No. (1) shows that the percentage of males in the study sample amounted to $(60 \%)$ while the percentage of females amounted to $(40 \%)$. The researcher must distribute the form to both genders, and the variation in the sample rates depends on the answer.

- $\quad$ Ages of the sample

Age is one of the most important factors in choosing a profession because there are a lot of jobs dedicated to ages and not others, and the study sample included the economically active community and the most able to work, whose ages ranged between (16-46) years.

Table No.2 Shows the ages of the sample and its variance in the study.

\begin{tabular}{|c|c|}
\hline Age & Percentage \\
\hline $16-20$ & $38 \%$ \\
\hline $21-30$ & $42 \%$ \\
\hline $41-46$ & $20 \%$ \\
\hline Total & $100 \%$ \\
\hline
\end{tabular}

The age groups of the study sample have been divided into three categories, as follows:

For the purposes of statistical analysis, Table No. (2) shows that $(38 \%)$ of the study sample is from the age group (15-34), with a percentage (42\%) who are currently employed, and it is the age group that is economically more active among the societal groups in the study sample and that $(20 \%)$ of the study sample is from the age group (41-46) years, which is the lowest percentage in the study sample.

- The educational level of the sample

Education is closely related to the profession, and the educational level is an aspect of choosing the profession and type of work.

Table No.3 Shows the educational level of the study sample

\begin{tabular}{|c|c|}
\hline The educational level & Percentage \\
\hline $\begin{array}{c}\text { Illiterate } \\
\text { read }\end{array}$ & $8 \%$ \\
\hline Primary education & $14 \%$ \\
\hline Secondary education & $18 \%$ \\
\hline University education & $25 \%$ \\
\hline Total & $35 \%$ \\
\hline
\end{tabular}

The most important criteria in determining the social status of the profession are the educational level, and Table No. (3) shows that the high percentage of degree holders (university or above) in the study sample reached (35\%), 
as the degree holders are usually motivated by social and material motives.

- Type of professions sample

The profession determines the personality of the respondent and clarifies many of the motives for his behavior and trends in social life.

Table No.4 Shows the professions of the study sample

\begin{tabular}{|c|c|c|}
\hline Profession Type & Number & Percentage \\
\hline $\begin{array}{c}\text { Free ( } \\
\text { nongovernmental })\end{array}$ & 63 & $63 \%$ \\
\hline Governmental & 37 & $37 \%$ \\
\hline Total & 100 & $100 \%$ \\
\hline
\end{tabular}

Table (4) It is notable that the number of those practicing free professions in the study sample amounted to 63 respondents, who constituted $63 \%$ of the study sample, while the number of those practicing professional professions reached (37) respondents, representing $37 \%$ of the study sample. Which the society practices affect the nature of his life and then the life of his family because it determines the income and standard of living of the families and the social class to which he belongs, in addition to his educational level. Its percentage reached (35\%), but the figure shows that $(63 \%)$ of the study sample are practicing liberal professions due to the lack of government jobs to include these university degree holders, many of whom were forced to engage in professions and self-employment.

Table No.5 Shows the distribution of occupational jobs by gender for the study sample

\begin{tabular}{|c|c|c|c|c|}
\hline $\begin{array}{c}\text { Profession } \\
\text { s }\end{array}$ & $\begin{array}{c}\text { Male } \\
\text { s }\end{array}$ & $\begin{array}{c}\text { Percentag } \\
\text { e }\end{array}$ & $\begin{array}{c}\text { Female } \\
\text { s }\end{array}$ & $\begin{array}{c}\text { Percentag } \\
\text { e }\end{array}$ \\
\hline $\begin{array}{c}\text { university } \\
\text { professor }\end{array}$ & $\mathbf{4}$ & $\mathbf{1 7 \%}$ & 6 & $\mathbf{2 7 . 2 \%}$ \\
\hline Teacher & $\mathbf{7}$ & $\mathbf{2 9 \%}$ & 6 & $\mathbf{2 7 . 2 \%}$ \\
\hline Engineer & $\mathbf{4}$ & $\mathbf{1 7 \%}$ & 3 & $\mathbf{1 3 . 6 \%}$ \\
\hline Physician & $\mathbf{2}$ & $\mathbf{9 \%}$ & 4 & $\mathbf{1 8 \%}$ \\
\hline $\begin{array}{c}\text { Gov- } \\
\text { Employee }\end{array}$ & $\mathbf{1}$ & $\mathbf{5 \%}$ & 4 & $\mathbf{1 8 \%}$ \\
\hline Officer & $\mathbf{2}$ & $\mathbf{9 \%}$ & ----- & - \\
\hline Lawyer & $\mathbf{1}$ & $\mathbf{5 \%}$ & 1 & $\mathbf{4 . 5 \%}$ \\
\hline $\begin{array}{c}\text { Services } \\
\text { Employee }\end{array}$ & 3 & $13 \%$ & ----- & - \\
\hline Total & 24 & $100 \%$ & 22 & - \\
\hline
\end{tabular}

It is noticeable that Table No. (5) there is a gender discrepancy in the job distribution of the study sample, as the jobs (university professor, doctor, and public employees) recorded high rates in favor of females, and this is due, according to our estimation, to the serious and high interest of females to practice these professions stems from Social appreciation of women working in these jobs, while the jobs new engineer, officer, service employee recorded high rates in favor of males, this may be due to the fact that these jobs are difficult in nature and require higher effort than other jobs, and the practitioner may have to move from one place to another to perform them, such as jobs the service that does not meet social approval in the view of the population of our society, and because of the high risk to its practitioners, especially military jobs such as (army officer or federal police that threaten the lives of its practitioners with death. The jobs (teacher, lawyer) recorded a great convergence between the ratios of male and female practitioners in the study sample and the figure below illustrates this.

\begin{tabular}{|c|c|c|c|}
\hline $\begin{array}{l}\text { Occupational } \\
\text { Professions }\end{array}$ & $\begin{array}{c}\text { Perce } \\
\text { ntage }\end{array}$ & $\begin{array}{l}\text { Freelance } \\
\text { Professions }\end{array}$ & $\begin{array}{c}\text { Perce } \\
\text { ntage }\end{array}$ \\
\hline $\begin{array}{c}\text { University } \\
\text { Professor }\end{array}$ & $27.3 \%$ & Goldsmith & $22.5 \%$ \\
\hline Teacher & $21.7 \%$ & Merchant & $16.4 \%$ \\
\hline Engineer & $14.8 \%$ & Mechanical & $15 \%$ \\
\hline Physician & $12.7 \%$ & Blacksmith & $12.3 \%$ \\
\hline $\begin{array}{c}\text { General } \\
\text { Employee }\end{array}$ & $10.6 \%$ & Carpenter & $11.2 \%$ \\
\hline Officer & $8.3 \%$ & Dyer & $8.2 \%$ \\
\hline Lawyer & $4.3 \%$ & Shop Owner & $8 \%$ \\
\hline $\begin{array}{c}\text { Service } \\
\text { employee }\end{array}$ & $2.3 \%$ & Taxi Driver & $6.8 \%$ \\
\hline----------- & ------ & Porter & $2,7 \%$ \\
\hline Total & $100 \%$ & Total & $100 \%$ \\
\hline & & & \\
\hline
\end{tabular}

It was found that the study sample was free of women practicing liberal professions, for reasons that are due to the nature of our society and the nature of social and security conditions that impede women's work in selfemployment such as (merchant, taxi driver, ..etc), which were restricted to males only, and on the other hand Her work was restricted to functional occupations only, and in this way the gender distribution was limited according to the functional occupations of the study sample.

8.2. The second topic: private data (specialized questions for the study) and its results 
- Young people's motives for choosing a profession.

Work has different motives that differ according to people's motives and the nature of conditions prevailing in society.

Table No.7 Shows the motives for choosing a profession

\begin{tabular}{|l|l|}
\hline Occupation Motives & Hierarchy \\
\hline High wages & 1 \\
\hline $\begin{array}{l}\text { Availability of opportunities for } \\
\text { development and prosperity }\end{array}$ & 2 \\
\hline Social statue & 3 \\
\hline Profession stability and sustainability & 4 \\
\hline Low risk and problems & 5 \\
\hline $\begin{array}{l}\text { The importance of the profession's work to } \\
\text { society }\end{array}$ & 6 \\
\hline Low effort & 7 \\
\hline
\end{tabular}

It is possible to note from Table No. (6) and Table No. (7) that the motives for choosing the profession varied in its hierarchical sequence according to its proportions. It is notable that the first motive (high wages) ranked first in the hierarchy with a percentage of $(27.3 \%)$, which means that the material need is the first motive for work Among the study sample, the high wage and material benefits associated with the profession, and Victor Fromm (2002) indicates that the wage and the associated material rewards are an important source of the sources that lead to an increase in the individual's desire to perform the profession, and increase the desire of young people in the profession and then continue In it, the wage is also linked to those benefits that are provided to individuals through insurance and retirement programs. The (availability of opportunities for development and prosperity) represents the second motive in the hierarchical sequence of the motives of the profession, as the person seeks to choose professions in which there are opportunities for advancement and material and social progress because it achieves reassurance (social and material). The social position ranked third because of its importance in selfrealization, respect and appreciation. The fourth motive in the hierarchy came (profession stability and sustainability), that the issue of the stability of an individual's work is linked to a number of important motives because the stability and stability of the profession means the stability of income for the individual and this achieves psychological and economic reassurance for the individual and from Then his family achieves this satisfaction with the profession because any threat to the individual's work reflects negatively on the financial return and his way of living. While, (low risk and problems) occupied the fifth motive in the hierarchy of the motives of the profession and recorded a percentage of (15\%), for every work has a type of danger and the severity of each work varies according to the practices of workers and the profession. Society for the practitioner may cause him social problems with the people around him.

It is clear that (the importance of completing the profession for society) occupied the sixth motive in the hierarchy of the motives of the profession, and a percentage of (11\%) was recorded. The person strives to practice professions that benefit society (producing goods and services and providing some of the needs of the environment in which he lives). Finally, (lack of effort) occupied the motive. The seventh of the hierarchical sequence of the motives of the profession and a percentage of $(7 \%)$ recorded, that the extent of energy or muscular or mental effort expended in professions is one of the important motives for choosing a profession that a person usually chooses behavior that includes spending the least amount of muscular and mental energy as possible and avoids actions that It requires a great muscular effort that may affect his health and expose him to disease.

- Motives for continuing in the profession.

Table No.8 Shows the motives for continuing in the profession

\begin{tabular}{|l|c|c|}
\hline $\begin{array}{l}\text { Motives for continuing } \\
\text { the profession }\end{array}$ & $\begin{array}{l}\text { The } \\
\text { number }\end{array}$ & $\begin{array}{l}\text { Ordinal } \\
\text { Sequence }\end{array}$ \\
\hline high wages & 81 & 1 \\
\hline $\begin{array}{l}\text { Unavailability of other } \\
\text { job opportunities }\end{array}$ & 50 & 2 \\
\hline $\begin{array}{l}\text { Deteriorating security } \\
\text { situation }\end{array}$ & 40 & 3 \\
\hline $\begin{array}{l}\text { My profession is not } \\
\text { subject to regulations } \\
\text { and laws that restrict me }\end{array}$ & 9 & 5 \\
\hline $\begin{array}{l}\text { Inability to practice } \\
\text { other professions }\end{array}$ & 192 & ------ \\
\hline $\begin{array}{l}\text { Total (the sample } \\
\text { answered more than one } \\
\text { choice) }\end{array}$ & \\
\hline
\end{tabular}

Table No. (8) shows the variation of the reasons why the sample members continue their professions without changing them, according to the needs of individuals and the nature of the social life they live. As (high wages) occupied the first rank in the hierarchy for the reasons for individuals continuing in a profession and not others. It is very natural. The deterioration of the economic conditions of the Iraqi family, due to the exceptional circumstances that our society is going through, has motivated the 
individual to resort to high-income jobs and professions to meet the family's needs and life requirements.

As for the reason (the lack of other job opportunities) it ranked second in the hierarchy for the reasons why individuals continue in one profession alone. It is very difficult for an individual who pursues a certain profession to change it to a new profession because there are many professions that need adaptation, adaptation and experience to achieve them in a way complete, in addition to the emergence of the specter of unemployment, which threatens thousands of residents of the community as a result of the exceptional circumstances that the community is going through for fear that there is no alternative profession to the current one, which constituted an obstacle to changing the profession.

The reason (the deterioration of the security situation) ranked third in the hierarchy of the reasons for the continuation of individuals in a profession alone. The deterioration of the security situation and the lack thereof posed a great danger to the residents of the community in terms of their professional practices, so many projects were frozen and many professions and businesses were banned, which led some to be committed and satisfied with the profession they practice, at least at the present time, and not to think about changing it.

On the other hand, the shortcomings in appointments. There are thousands of graduates and holders of different degrees who are unemployed and unable to find a job commensurate with their abilities and academic qualifications, and the reason came (my profession is not subject to regulations that restrict me) ranked fourth in the hierarchy for the reasons why individuals continue in a profession and nothing else. The adherence, commitment and routine in many professions motivated their practitioners to abide by them and not to change them, because coercive regimes stress their practitioners and this may reflect negatively on their responses and hinder their work.

The reason (the inability to practice other professions) ranked fifth in the hierarchy for the reasons why individuals continue to pursue a profession alone. Continuing in a profession alone due to psychological, material and social disability leads the individual to frustration in changing professions.

Finally, we note the variation of reasons for the residents of Baghdad to continue in a profession without changing it, some of them (economic), including (social), and including (psychological) affected the choice of profession and continue to practice it.

- What is the preferred free profession for young people at the present time?
This question was distributed to the study sample of young people from the age of (16 to 30), and they constituted $80 \%$ of the sample size.

Table No.9 Shows the liberal professions preferred by young people.

\begin{tabular}{|c|c|}
\hline Free Professions & Percentage \\
\hline Merchant & $31.9 \%$ \\
\hline Goldsmith & $25.5 \%$ \\
\hline Mechanical & $12.8 \%$ \\
\hline Goldsmith & $6.5 \%$ \\
\hline Carpenter & $2.1 \%$ \\
\hline Dyer & $2.1 \%$ \\
\hline Shopkeeper & $14.9 \%$ \\
\hline Taxi Driver & $4.2 \%$ \\
\hline Total & $100 \%$ \\
\hline
\end{tabular}

The above table shows that there is a discrepancy in the preference of free professions by employees in the study sample. The profession (Merchant) recorded the highest percentage $(31.9 \%)$, although it is a profession that exposes many of its practitioners to kidnappings, threats and killings under these conditions prevailing in society. Perhaps the most important reason for preferring this profession was that its owner or practitioners are not bound by restrictions or conditions with others, which is the command and the prohibition, as well as the high return and profits of its owner, and its owner has achieved psychological and social respect and appreciation among the population of the community. In addition, the profession of merchants leads its practitioners to build new social relationships by virtue of the profession, and through this societies view the merchant as having a good personality and characterized by intelligence. These professions are characterized by high social considerations and enjoy an advanced position in the gradual hierarchy of professions in the eyes of our society.

As for my profession (shop owner, taxi driver) it recorded few percentages in the gradual ladder of the job pyramid, as it is not given importance and appreciation by the residents of Baghdad society, especially the low profits and income.

Table No.10 Shows the professions preferred by the selfemployed.

\begin{tabular}{|c|c|}
\hline Occupations & Percentage \\
\hline University Professor & $26.7 \%$ \\
\hline Teacher & $17.8 \%$ \\
\hline Physician & $13.6 \%$ \\
\hline
\end{tabular}




\begin{tabular}{|c|c|}
\hline Engineer & $11 \%$ \\
\hline Public Employee & $10.9 \%$ \\
\hline Lawyer & $10.7 \%$ \\
\hline Services Employee & $6.4 \%$ \\
\hline Officer & $4.1 \%$ \\
\hline Total & $100 \%$ \\
\hline
\end{tabular}

Table No. (10) shows the variation in the respondents' answers about the preference for occupational professions due to their differing opinions on the one hand, and the differences in the characteristics and qualifications of professions on the other hand. A percentage of (17.8\%) and this is an important indicator of the importance of the two professions in building society through education. Occupational professions (doctor, engineer, public employee, and lawyer) have a significant convergence in the percentages, that the interest in the job aspect recently due to the high salaries and the continuity of the profession and the stability of its income.

As for the profession (new officer in the army or the federal police), it recorded the lowest percentage $(4.1 \%)$ among the respondents. At the lowest and least proportions, it is due to the threat and risks to which its practitioners are exposed under the circumstances that society is going through.

Therefore, it is possible to realize that the above professions have three motives:

The first is to obtain a new wage for his work.

The second / psychological is the individual's desire to achieve his goals.

The third / social for its social position in society.

- An arrangement of occupations according to their priority and importance to the respondents.

In the table, most of the functional and free professions practiced by the residents of the city of Baghdad are mentioned. The main goal is to reveal and clarify the community's motives towards practicing functional and free professions, as well as revealing that these professions have an advanced social position in the hierarchy of professions in society.

Table No.11 Shows the hierarchical sequence of occupations

\begin{tabular}{|c|c|}
\hline $\begin{array}{c}\text { Occupations / } \\
\text { Professions }\end{array}$ & Hierarchy \\
\hline University Professor & 1 \\
\hline Physician & 2 \\
\hline Engineer & 3 \\
\hline
\end{tabular}

\begin{tabular}{|c|c|}
\hline Teacher & 4 \\
\hline Lawyer & 5 \\
\hline Officer & 6 \\
\hline Public Employee & 7 \\
\hline Services Employee & 9 \\
\hline Merchant & 10 \\
\hline Goldsmith & 11 \\
\hline Mechanical & 12 \\
\hline Blacksmith & 13 \\
\hline Carpenter & 14 \\
\hline Dyer & 15 \\
\hline Shop Owner & 16 \\
\hline Taxi Driver & 17 \\
\hline Porter & 8 \\
\hline
\end{tabular}

Table No. (11) shows that occupational occupations occupied the first five ranks of the hierarchy of occupations for their priority and importance, which are as follows (university professor, physician, engineer, teacher, lawyer, officer, public employee, service employee) and this shows the respondents' interest in government occupations for the reasons ( economic and social), from the economic point of view the increase and improvement of the monthly income of these professions at the present time compared to previous decades, in addition to that the job profession guarantees its practitioner a constant monthly resource and achieves pension security in the future or (guarantees his pension right), this means the improvement in the monthly salary of the job is reflected Positively on the motives and trends of society in the Iraqi society, there is no doubt the improvement in the pension salary.

As for the social aspect, ensuring future rights created an atmosphere of psychological and social comfort for the community working in the career profession, and this in turn poured into the social reality of the community, as the standards of social status began to change, and even the profession of an officer (federal police / army) gained this job the advanced ranks of the hierarchical sequence of occupations, despite the risks that afflict the owners of these professions, there is still great respect from society for the owners of these professions, there is no doubt that Iraqi society still respects power and prestige.

As for the free non-governmental professions, they came after the functional professions in their importance and priority for the population of the Iraqi society. This in turn confirms the reasons mentioned by the study sample members above. There is no doubt the insecurity that 
prevails in the community, which in turn hinders a lot of society in the practice of these professions, and there is no doubt that most of them need an atmosphere Stable security as professions (trade, goldsmith, mechanic..etc).

Finally, it can be said that the motives for choosing professions in Iraqi society (Baghdad) varied and varied, including economic, social, and security ones.

\section{CONCLUSION}

the results of the study have been concluded as the following:

- From the results of the study, it was found that the occupational ranking of the occupations practiced by the residents of the city of Baghdad varied in terms of their social and economic importance.

- The study concluded that there is a difference in society's motives towards choosing a profession and practicing it, and that is related to the nature of their personal qualifications on the one hand, and what they get (financially and morally) from this profession, as follows:

- High wages

- Opportunities for development and prosperity

- Profession stability and sustainability

- Low risk and problems

- The importance of fulfilling the profession for society

- Less effort.

- The study indicated that (the high wages of the profession) occupied the ranks of the hierarchy and has a high social position, the deterioration of the economic conditions of the Iraqi family due to the exceptional circumstances that our society is going through, motivated the individual to resort to jobs and professions with high incomes to meet the needs of the family and its life requirements. Undoubtedly, society is characterized by the economic character that has made materialism a criterion for social preference to some extent.

- The study also found that there is a clear variation and difference in the types of professions practiced by the residents of the city of Baghdad. We note from Figure No. (2) that $(63 \%)$ of the study sample practice free professions, and that (37\%) practice functional professions, The profession practiced by the community affects the nature of his life and, consequently, the life of his family because it determines the income and thus determines the standard of living of the families and the social class to which he belongs, as well as his educational level. This is an indication that the people of the city have adapted to the conditions in practicing new professions despite the circumstances that prevented them from performing their normal professions (because many of them changed their professions due to the exceptional circumstances of the city - such as the deterioration of the security situation in the areas of their previous work, some forced to resort to new jobs), and here The second objective of the study (recognizing the types of professions practiced by the residents of Baghdad) was achieved.

- The study indicated that there are additional motives and reasons that made the city's residents to continue in a profession without changing it, which are as follows:

- High wages

- Unavailability of other job opportunities

- Deteriorating security situation

- My profession is not subject to regulations that restrict me

- Inability to practice other professions

Here, the third objective of the study was achieved, which is (there are motives for additional reasons that lead society to continue in a profession without others).

- Table No. (11) shows that occupational occupations occupied the first five ranks of the hierarchy of occupations for their priority and importance, which are as follows (university professor, physician, engineer, teacher, lawyer, officer, "federal police, army", public employee, service employee) and this is between the respondents' interest in government job occupations for (economic and social) motives.

As for the free non-governmental professions, they came after the functional professions in their importance and priority for the population of the Iraqi society. This in turn confirms the reasons mentioned by the study sample members, especially the insecurity that prevails in the community, which in turn hinders many of the society in practicing these professions and that most of them need a stable security atmosphere As professions (trade, goldsmith, mechanic and others), and here the fourth objective of the study was achieved to reveal the hierarchical sequence of the occupations practiced by the residents of the city of Baghdad. 


\section{RECOMMENDATIONS AND SUGGESTIONS}

Based on the results of this study, the researcher developed a set of recommendations and suggestions, which are as follows:

- The results of this study can be used in developing plans and programs by the concerned authorities and state institutions, no doubt the Ministry of Planning, the Ministry of Labor and Social Affairs, the Ministry of Higher Education and Scientific Research, and youth organizations, in order to create balance and contain the energies and efforts that support development plans.

- Providing suitable job opportunities for young people and expanding their fields in the field of career work as well as opportunities that are within the field of specialization that the student studied in order to develop work and the individual working in it at the same time, and this falls on the shoulders of the ministries and departments of the state.

- Seeking justice in distributing job opportunities for young people and focusing on efficiency and quality more than anything else.

- Developing curricula and curricula for education in the humanities disciplines and making them keep pace with the developments of the times and closer to the practical reality, both career and free, and provide job opportunities for young people in the humanitarian disciplines.

- The use of the media in order to educate individuals and strengthen their attitudes towards career work and self-employment, so that individuals in all social classes can identify the characteristics and advantages of each job, and highlight through them the vacant job opportunities and sectors that need labor in order to make room for young people to Take it up and work on it.

- In order to contain the energies of young people and rid them of unemployment, there is no doubt that when there are no job opportunities in career work, even if it is for a certain period, it is necessary to help support their efforts and provide them with job opportunities in the private sector or help them to conduct their own projects and provide the capital for their investment, and provide a measure of safety and security for them as a result of these actions.
- Creating a balance between workers in the field of career work and workers in the field of selfemployment in order to promote sound development plans, through development programs presented by the media, and there is no doubt when one of the sectors significantly dominates in terms of the number of workers in the other sectors.

- $\quad$ Providing the opportunity for women's work and keeping them in line with men's job opportunities through the concerted efforts of the entire community institutions.

- Conducting a similar study after a certain period of time in order to reveal the trends of young people towards career work and self-employment and to identify the changes that occur there and compare its results with the results of the current study.

- Doing a field study to find out the influences and motives that affect young people's choice of the type of work.

\section{REFERENCES}

[1] Abdel Basset A, (1995 ). Some Social Variables Affecting the

Relationship Between Education and Human Development in the Arab World(A. Mustafa, Trans.). Beirut: Center for Arab Unity Studies. p. 297.

[2] Ahmed, M, (1984). The facilitator in Social Psychology(A. Mustafa, Trans.). Amman: Dar Al-Furqan Publishing. p. 145.

[3] Ahmed A, (1990). A future vision to enhance the social status of the profession in the Arab world, Mutah Journal for Research and Studies, No. 2, , p. 103.

[4] Ahmed A, (1991). Performance Evaluation and Job Description, Mutah Journal for Research and Studies, Issue 4, , p. 210.

[5] Ali S, (1993). Sociology Theory(A. Mustafa, Trans.). Egypt: University Youth Foundation. p. 54.

[6] Awad, M. (1988). In Social Psychology(A. Mustafa, Trans.). Alexandria: University Knowledge House . p. 27.

[7] Brown, C, (1971). The Social Psychology of Industry, Britain: Cambridge. P. 161.

[8] Hassan, M, (1971). The Origins of Social Research(A. Mustafa, Trans.). Cairo: Anglo-Egyptian Library. p. 172.

[9] Hisham, A. (2001). Some demographic variables and their impact on the social standing of the profession, Journal of Social Sciences, No. 3, p. 692.

[10] Hisham, A. (2001). Some demographic variables and their impact on the social statue of the profession, Journal of Social Sciences, No. 3, p. 693. 
[11] Ibrahim M, (1975). Dictionary of Social Sciences(A. Mustafa, Trans.). Cairo: Egyptian Book Authority. p. 560.

[12] Ihssan A, (1990). Sociology of Economics(A. Mustafa, Trans.). Baghdad: Dar Al-Hikma for Printing and Publishing. p. 65.

[13] Ma'an O, (1990). The Fission of the Social Terminology(A. Mustafa, Trans.). Baghdad: Ministry of Higher Education and Scientific Research. p. 78.

[14] Mansoor A, (2002). Residents of the Arab World (A. Mustafa, Trans.). Iraq: House of Wisdom. p. 339.

[15] Mansoor A, (2002). People of the Arab World(A. Mustafa, Trans.). Iraq: House of Wisdom. p. 339.

[16] Michael D, (1980). Dictionary of Sociology(A. Ihssan, Trans.). Baghdad: Dar Al-Rasheed Publishing. p. 77.

[17] Mohammed A, (1986). Professional Ethics(A. Mustafa, Trans.). Al- Jordan: Risala Al-Hadith Library. p. 73.

[18] Mohammed A, (1985). Society, Culture and Personality(A. Mustafa, Trans.). Cairo: Dar Al-Maarif Al-Jamiah. p. 124.

[19] Sufouh A, (1980). Society Science and Development Issues and Planning (A. Mustafa, Trans.). Damascus: Publications of the Ministry of Culture and National Guidance. p. 484.

[20] William L, (1964). Dictionary of the Social Sciences, New York: The Free Press. p. 216. 